\title{
Palestinian Education amidst a Complex History and a Fragile Peace
}

\author{
Jeffrey S. Burwell, SJ \\ St. Paul's College at the University of Manitoba, Canada
}

\begin{abstract}
The complicated relationship between Israel and Palestine has regularly had a negative influence on Arab education in the region. The first intifada in 1987 and the second intifada in 2000 each moved the Israeli Defense Force to identify Palestinian schools as a threat to national security. This paper begins by highlighting how the history of Palestinian education and how these intifadas affected Palestinian schools today. More specifically, it focuses directly on how each intifada created situations of disorder within the Palestinian educational system. It also seeks to demonstrate - using extensive data collected from 14 schools in East Jerusalem and the West Bank - how education in the region has returned to some level of organizational normalcy after the intifadas. No longer does the Israeli military control the daily operations of Palestinian schools in definable ways. Rather, despite the ongoing challenges facing the two states, Palestinian schools are now functioning with higher levels of routine and a greater sense of ease than they have since about 2005.
\end{abstract}

\section{Introduction}

Particularly since the emergence of the first intifada in 1987, the relationship between Israel and Palestine has had moments of tension and tragedy. This fractured bond has been the cause of many casualties; without doubt, one of the most visible has been Palestinian education. Over the last twenty-five years, schools in East Jerusalem and the West Bank have been trigger points for violence between the Israeli Defense Force (IDF) and Arab youth. These schools, as scholars have observed, were frequently identified by the Israeli authorities as gathering points for those who social and political resistance against the Israeli state. With recognition that the Israeli-Arab conflict is an important international concern, this paper outlines how the continued struggle has affected Palestinian schools since the first intifada and how it continues to impact them today. Relying heavily on data from interviews with administrators of fourteen schools as well as data from both teachers and staff members, it appears evident that - despite the range of issues that continue to affect the two sides - the vast majority of Palestinian schools in both East Jerusalem and the
West Bank are now functioning with considerably higher levels of routine and a greater sense of ease than they have in almost an entire decade.

\section{History of the Conflict}

To provide an overview of the conflict, it is best to begin by highlighting one of the most concise and recent summaries of Palestinian education. Written by Abu-Saad and Champagne in 2006, their work entitled A Historical Context of Palestinian Arab Education claimed that Palestinian education can be divided roughly into five distinct epochs. The first and second are the Ottoman period from about 1516 and the British Mandate period from 1917.

The third epoch comprises the 19 years from the establishment of Israel in 1948 until the Six-Day War. The fourth is the post-1967 period from the Israeli occupation of the West Bank and Gaza Strip until the Oslo Agreements. The fifth started with these agreements in 1993 and continues until today. To contextualize their historical survey, Abu-Saad and Champagne stated "formal public education in Palestine, from its very beginnings, was never under the control of the Palestinian people" [1]. Although the Palestinians have control over their educational system today, the modern situation cannot be grasped without outlining its complex and circuitous history.

The two scholars thus made an initial claim that the Ottomans introduced formal education into Palestine only toward the end of the 19th century. Before this period, education was typically limited to the elementary level. They additionally made note that an organized system of schools, modeled on the post-revolution system in France, emerged in 1869 only. Yet, even with a formal structure, they highlighted how "the Ottomans simply followed the French curriculum, which meant the French textbooks were translated into Turkish and that French standards were adopted" [1].

Because the Ottoman Empire allowed nonMuslim religious communities to maintain social, political, and religious autonomy, Christian schools (such as the Franciscan school in Bethlehem) typically functioned according to their own criteria. Although the early Christian schools taught mostly in Arabic, which is still the case today, these nonMuslim schools often adopted as a second 
instructional language the national language of the religious order administering the school. During this period, most of the educational institutions were elementary schools. Students who wanted to attend high school often went to Damascus, while those who wanted to attend university ended up in military schools either in Istanbul or other parts of the Ottoman Empire.

This system of education changed only slightly under the British Mandate; either the government or religious communities continued to administer most schools. Despite the historical reputation of the British as a nation focused on education, Abu-Saad and Champagne claimed that "as late as 1946, only $22 \%$ of the school-age population was enrolled in public schools, as compared to $12 \%$ in 1914 during Ottoman rule" [1]. Enrolment did not increase under the British Mandate, at least not until the Zionist influx into Palestine itself changed the social and religious dynamics of the region. It was only at the conclusion of Second World War that varieties of Jewish schools quickly began to emerge alongside the Islamic and the Christian schools.

Although the British Mandate claimed to provide full access to public education for all, Abu-Saad and Champagne suggested that the British fostered Jewish nationalism and favoured the Zionist movement over Arab interests. This essentially meant that the Palestinian schools "suffered from budget cuts; a lack of facilities, personnel, and local autonomy; and administrative limitations imposed by the colonial governing apparatus and its Department of Education" [1]. This bias manifested itself in that the Jewish community in Palestine was granted charge of its own educational institutions by British authorities while the Arab population was denied any real control over their schools. The authors' essential point was that a two-tiered, two-class educational system developed under British control: the Jewish community and their schools were favoured at the expense of the Arab population. This great dichotomy in educational organization, they argued implicitly, laid the foundations for a weak system of Palestinian education that lingers to this day.

When the British Mandate ended and the Jewish community established Israel as their political and spiritual homeland in May 1948, Arab interests were not a priority. According to Abu-Saad and Champagne, "more than 700,000 Palestinian Arabs fled ... or were expelled from the newly established state of Israel and only 160,000 remained within its boundaries" [1]. At this point, neither the Gaza Strip nor East Jerusalem and the West Bank fell under Israeli jurisdiction: Egypt and Jordan respectively had political control these two regions. All the same, the administration of Palestinian schools changed as a result of the shift from British control.

The majority of the Palestinians in Israel after the declaration of independence attended educational institutions run by Israel; those in the Gaza Strip and the West Bank attended schools administered by Egypt and Jordan respectively. In addition, the United Nations Relief and Works Agency played a role in the education of Palestinian youth immediately following 1948 insofar as they established a number of schools in refugee camps in the Gaza Strip, West Bank, and in neighbouring countries. Depending on the location of a Palestinian family in the region after 1948, Arab students might have followed academic curricula from Israel, Egypt, Jordan, or modifications of all three.

Although a major political shift occurred in 1967 when Israel seized the Gaza Strip and the West Bank during the Six-Day War, Palestinian education in the two regions did not change dramatically. As both Abu-Saad and Champagne maintained,

Palestinian education under the Israeli occupation was controlled and directed by the military administration. The Jordanian and Egyptian curriculums used for the provision of education in the West Bank and the Gaza Strip, respectively, since 1948 were kept by Israeli authorities, with some modifications, after the occupation began [1]

Over time, however, Palestinian schools became trigger points for violence between the Israeli Defense Force and Arab youth. In the Gaza Strip and the West Bank, any signs of Palestinian autonomy such as national flags, songs, and dress were forbidden by the Israeli military. Nevertheless, this suppression only raised the Palestinian desire to forge a national identity. The universities, where most students gathered on a regular basis, soon became the "centres of political struggle and national resistance" [1]. The first Palestinian uprising (intifada) that began in 1987 had a huge impact on Palestinian education, especially since the Palestinian schools were seen by the Israeli military as potential threats to national security.

Despite the long history, at its most basic, the present tensions between the Israelis and the Palestinians can be traced to the first intifada. What began as a minor uprising in one small Palestinian refugee camp, established after the 1948 war, grew to involve Palestinians in the Gaza Strip, Israel, and the West Bank. This first uprising lasted from 1987 until 1993 and claimed the lives of at least 180 Israelis and more than 1400 Palestinians [11]. Despite its dramatic and far-reaching effects, very little attention was initially paid to its influence on Palestinian education. In fact, it would seem that only one small group within Palestine successfully made this connection. A human rights collective that called itself al-Haq emerged out of Birzeit University near Ramallah and published materials on how Arab schools were methodologically targeted by the Israeli military. As the alarming events connected to the 
first intifada dramatically unfolded in late 1987, the organization regularly addressed how Palestinian education had become one of the first casualties of the uprising. Al-Haq starkly commented,

When soldiers or police stop students because they have books, invade buildings looking for classrooms or question teachers and warn them that they must not teach, there is no possible security rationale: it is education itself that is the criminal activity under scrutiny [3].

Almost immediately, many Palestinian schools in the conflict zones were monitored and highly regulated. The fledgling revolution had prompted a serious response from Israel that had repercussions on Arab schools throughout the region.

Although Palestinian schools suffered during the first intifada, academics seemed to focus more on the physical or the psychological issues connected to the violence than its negative influence on Arab schools. For example, Lockman and Benin noted the physical toll in a critical study that identified how almost $40 \%$ of the then 390 Palestinians who died in the first year of the uprising were less than 18 years old [12]. Additionally, academics such as Maker and Graff were able to make the many psychological connections by noting in detail the detrimental effects that the intifada had on children [6] [13]. Lastly, a study conducted by Miller, El-Masri, Allodt, and Quota shortly after the first intifada ended looked at 669 school-aged Palestinian children in order to determine the connection between trauma exposure and emotional or behavioural problems [15].

Any of these key issues would naturally have an influence on Palestinian education, since they all involved school-aged children. Nevertheless, the vast majority of academics had not initially considered the connection explicitly. It was only at the end of the second intifada that some scholars such as Ra'ad and Nafi as well as Nicolai began to note with intentionality that, "when the first intifada erupted in December 1987, the impact on education was dramatic" [16] [18]. The acknowledgment that the first intifada had influenced Palestinian education came slowly. However, when it did, the deep relationship was undeniable.

An article by Hussein, as one example, explained the connection between the uprising and education in East Jerusalem and the West Bank. Using a number of the al-Haq briefs, she showed how "Palestinian education - formal and informal - became illegal as Israel closed schools and universities indefinitely and Israeli soldiers harassed and arrested students and teachers for participating in underground classes or for even carrying books" [8]. She revealed how Palestinian schools were already in disarray at the start of the first intifada: most school buildings were inadequate, classrooms were overcrowded, and some of the most essential tools for teaching were unavailable. With textbooks and curriculum in the Gaza Strip and the West Bank administered by Egypt and Jordan respectively, the first intifada is now seen as having only further compromised an already weak system. As she continued,

Palestinian students never knew when or whether they could go to school on any given day between 1988 and $1990 \ldots$... During those years, Palestinian schools were allowed to convene for as little as $17 \%$ and no more than $50 \%$ of their school year.

Although the events connected to the first intifada hindered Palestinian education, the Oslo Accords of 1993 established a definite framework around which Israel and Palestine could move - for the first time in many years - beyond the conflict and violence.

The secretive 1993 meetings conducted in Oslo and ratified in Washington ended the first intifada and dramatically changed the relationship between Palestine and Israel. In his memoirs, Bill Clinton wrote that "all the world was cheering" after the famous handshake between Yassar Arafat and Yitzhak Rabin [5]. The event suggested to many that the two states might finally have achieved a lasting amity. From a practical perspective, the Oslo Accords led to Israeli recognition of the PLO as the official Palestinian government and provided them control over a number of zones in the Gaza Strip and the West Bank. The accords also gave Palestinians authority over their own educational system and allowed them to move it in a new direction. Although the accords had many diverse implications, they had a most remarkable impact on Palestinian education. In particular, the repercussions led to the establishment of a variety of new peace-education initiatives. With the many changes that took place, the years following the accords were filled with anticipation and optimism.

Those with an interest in peace education had a particular reason to be optimistic. Never before had Israeli and Palestinian leaders come together so publicly and cordially. Many in both the Middle East and abroad could not help but feel that peace was a real and lasting possibility. In that light, varieties of peace-education programs emerged immediately. Although they were facilitated by various organizations and used different approaches, most of the programs sought to bring Israeli and Palestinian youth together. Two of the most notable programs were the Seeds of Peace program and the peace education program implemented by the IsraelPalestine Centre for Research and Information. The two programs have been covered extensively in the media and journals because of their focus on building strong relationships between Israelis and Palestinians. Their legacy reveals a great deal about 
the educational climate that existed in Israel and the Palestinian territories following the Oslo Accords.

In the first instance, a journalist named John Wallach founded the Seeds of Peace program within months after the accords. The initial aim of the program was to bring together Palestinian and Israeli youth for three weeks in a neutral location to work through prejudices, anger, and hurt in order to achieve mutual recognition of each other. Although various academics have referenced his work, Wallach himself wrote that the Seeds of Peace Program was "about making real peace in the real world. It's about changing attitudes, ending the fears and prejudices that have prevented entire generations from getting to know one another; in short, it is about rehumanizing, not dehumanizing, the enemy" [23]. The program believed that enemies could become friends once faces from the other side of the conflict could be connected to names. The Seeds of Peace program worked to establish interpersonal bonds by highlighting common ground between individuals. Participants learned that personal encounters could move individuals to think beyond us versus them and to achieve a we-mentality.

In the second instance, the Israel-Palestine Centre for Research and Information (IPCRI) program was established in 1996 under the direction of Baskin and Qaq. Academics have often noted that the program provided participating schools in Jerusalem and the West Bank with a comprehensive peace-education curriculum. Indeed, it intended "to impart values of tolerance and acceptance... recognition of the equal right to liberty ... and an encounter between Palestinians and Jews" [10].

The IPCRI program brought trained facilitators directly into Israeli and Palestinian schools and worked with principals, teachers, and advisors within high school classrooms. Funding for this program initially came from organizations such as Yad HaNadiv, Keren Bracha, People-to-People, and the British Council as well as international governments such as the United States of America, Sweden, Norway, Switzerland, and Holland. Despite its success, it was discontinued in early 2004 due to financial constraints.

Although peace-education was a major focus for many once the Oslo Accords were signed, others were also interested in how Palestinian control over their own education provided new opportunities to forge a national identity. The years following the 1993 signing were a not only a time of great change but also of great effort as Palestinians sought to build a new society with their new freedoms. Related specifically to the development of both their educational system and their national identity, Sachs published an article in the Ottawa Citizen that identified Palestinians' major struggles. For the first time in history, as Sachs pointed out,
Palestinians of the Gaza Strip and the Israelioccupied West Bank are running their education. Students and teachers salute the Palestinian flag, engrave the names of "martyrs" on the school entrance, sing the Palestinian anthem, and give history and ethics their own defiant spin [20].

The agreements provided Palestinians with a chance to establish themselves through their own educational system: identity, heritage, religion, culture, and language were now fully in the hands of a people who - for so long - had known no control over their own classrooms. It was an exciting time to be a Palestinian educator; academics around the world took note.

On August 24, 1994, a Toronto Star article described the change in control over Palestinian education. The short report by Reuters news agency explained how Palestinians would have complete control over certain areas by September 1, 1994 - in time for the start of school, even though "divergent views emerged during the meeting, notably regarding Jerusalem and settlements" [19]. An article by Jon Immanuel, published in the Jerusalem Post just a few days before, echoed this sentiment. It read,

Earlier in Ramallah, an Israeli and a Palestinian educator signed documents, shook hands, and launched the second stage of the IsraeliPalestinian peace process, which will extend some Palestinian authority to the rest of the territories. The transfer of administration over education in Ramallah is to be followed by a similar transfer in Nablus, Jenin, Bethlehem, and Hebron by Sunday [9].

Within two years of the transfer of educational authority to Palestinians, al-Haj wrote a very comprehensive work on Palestinian education, its relationship to the Israeli occupation, and its role in facilitating a specifically Palestinian state. This work seemed to summarize the beliefs of Arab administrators and teachers by suggesting that education itself may be the primary way in which the Palestinian minority, who have historically lived under foreign regimes, might emancipate themselves fully from such control [2]. Many of the Israelis saw the Oslo Accords as providing the Palestinians an opportunity to change their future; the international community looked to the region with positive anticipation.

Despite the positive energy surrounding the Oslo Accords, tensions continued to grow between Israelis and Palestinians during the following years; the second intifada - described often by Palestinians as the Al-Aqsa Intifada - exploded in September 2000. It is widely agreed that the trigger for the second uprising was one of at least two related events. Glick wrote that the intifada itself began on Wednesday, September 27, 2000, "when a Palestinian security 
officer on a joint patrol with Israeli forces turned his firearm on his Israeli counterpart and murdered him" [7]. Sharon suggested, by contrast, that the uprising might have actually begun when he paid a visit to the Temple Mount as part of his campaign for Prime Minister on Thursday, September 28, 2000 [22].

Although the Jewish and Islamic traditions both consider the area sacred, it was understood by most to be under the direct religious control of the Islamic authorities since the Dome of the Rock and the AlAqsa mosque rest on the site. All the same, Sharon asserted that offence was taken to his visit because he stated boldly that Jews also have an eternal right to visit the spot. Whether triggered by the events of that Wednesday or Thursday, passions surged very high among Muslims by the time they gathered for their Friday prayers.

A number of dreadful clashes took place between Israeli soldiers and Arabs from the Gaza Strip and the Palestinian territories at the end of September 2000 and the beginning of October 2000. McNally reported that the Arabs in the region resorted to tactics such as rock throwing and firebombing, while the Israelis used tear-gas, rubber bullets, and even live ammunition [14].

A flashpoint occurred when two Israeli reservists were detained on October 12, 2000 by Palestinian authorities for passing the Israeli checkpoint into Ramallah. After hearing that two soldiers were being held, a mob gathered outside the police station. A $\mathrm{BBC}$ report claimed the group was so deeply angered by "the funerals of about 100 Arabs, nearly two dozen of them children" over the previous two-week period that they stormed the building and lynched the soldiers [4]. The bodies of the men were thrown from the windows before they were then taken to AlManara Square and further dishonoured. The Israeli military responded to this incident swiftly, and tensions were further enflamed.

This, of course, was a dramatic turn of events; it was quite unexpected by most in the academic world. For example, an article by de Santisteban revealed just how quickly the social and political situation in Israel and the Palestinian territories had changed. He began his 2002 article, which was an exploration of the anticipated national curriculum in the Gaza Strip and the West Bank, by stating,

While this paper was being written, newspapers and political commentators in Europe and in the United States were celebrating, together with their Israeli counterparts, the results of the last Israeli elections, which gave the victory to $\mathrm{Mr}$ Ehud Barak, now the new Prime Minister of Israel [21].

Like others, he presumed that the election would usher in an era of peaceful negotiations between Israelis and Palestinians. Of course, Barak was only in office for about a year before the second intifada began. By the time that de Santisteban's article was published, Barak was replaced and many Palestinians had already embraced the second intifada. Events in the region continued to move very quickly; both international observers and academics found the situation difficult to follow.

From September 2000, it took scholars about 15 months to begin publishing about the new reality in the region. Yet, unlike the response to the first intifada, which did not initially make the connection between the uprising and education, the relationship was much more obvious the second time around. In the period between 2002 and 2005, a number of articles saw that the intifada was having and would continue to have a negative impact on Palestinian education. For example, Zureik, in her article entitled "Palestinian Education in Disarray," observed that more than half the Palestinian population was under the age of 15 years of age. As such, education would need to play an important role in the struggle for a national identity. Despite this, she maintained,

For the last 35 years, Israel has embarked on confiscating land, building settler colonies and a network of bypass roads for exclusive Jewish use, slicing up the Palestinian localities into noncontiguous regions ... imposing tight control over movement of peoples in the territories, and exercising sole authority over water resources [24].

Although she did not reference the second intifada, mostly because it was not yet widely known as such, she noted that the military presence in the West Bank had prevented Palestinians from obtaining with any ease an education that might enable them to become self-determined. An inability to attend school with complete freedom effectively meant that Palestinians were obliged to live as second-class citizens. The vital role that education should play in the on-going development of a national identity for Palestinians thus remains a worthy topic for academic reflection.

\section{Methodology}

All the same, few scholars have endeavoured to explore Palestinian education since the end of the second intifada in 2005. Therefore, in addition to highlighting the history of the conflict, this short paper also sought to identify the many contemporary challenges facing these schools. To obtain the data for such a study, fourteen Palestinian schools from Jerusalem, Ramallah, Bethlehem, Beit Jala, Jericho, Beit Sahour, and Taybeh (Figure 1) were selected. Two-hour long interviews with school leaders were conducted to determine how they perceived the ongoing strife between the two states to influence their schools. The selected administrators were between 35 and 75 years old, and the group was 
comprised of 11 men and 3 women. Only three of the fourteen school leaders had completed some sort of graduate degree in educational administration, and each of the others had various other levels of formal training. All of the schools selected were within a 25-kilometre radius of the city of Jerusalem, which is considered by most to be the epicentre of the IsraeliArab conflict. Each of the administrators claimed to be employed during the second intifada as either a teacher or a school leader.

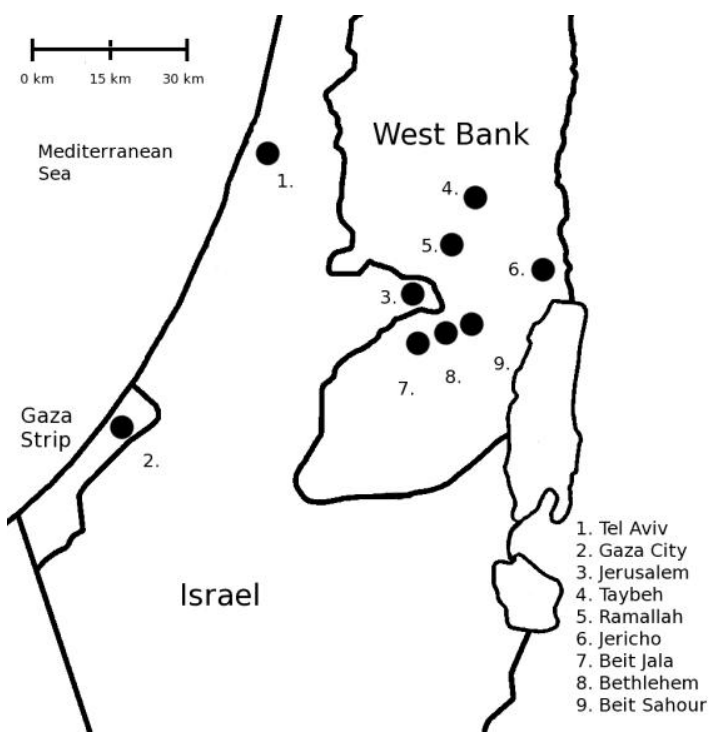

Figure 1. Map of Israel and the West Bank

\section{Israeli National Security}

The interviews with administrators touched on a variety of different topics, yet there was a primary focus on how the relationship between the two states and Israeli national security influenced Palestinian education. Various interview questions set the tone for the meetings, but each of the interviews was allowed to move in any direction based on the school leader's thoughts or desires. Although the interviews provided the majority of the data presented in this paper, supplementary evidence was also obtained from conversations with staff members and teachers. At the conclusion of the data collection, isolation of identified challenges revealed how administrators of Palestinian schools see both Israeli national security and the Israeli Defense Force as affecting their schools today. Despite continuing challenges facing Palestinian schools, the research suggested that most administrators did not feel that Israeli national security has the same influence on Palestinian education today as it did during the intifadas.

This was quite surprising since - before the data collection was completed - I had formulated the hypothesis that Israeli national security would have had a continued influence on Palestinian schools. In fact, a number of the interview prompts specifically sought to explore the military's influence on daily school operations. Despite this mistaken supposition, data collection revealed that very few school leaders considered the Israeli Defense Force to be a challenge. Although it is true that checkpoints were observed on $74 \%$ of major West Bank roads as recently as 2010, only one administrator from an East Jerusalem school and one from the West Bank school identified the Israeli defence force as a real administrative concern [17]. Today, large numbers of Palestinians still spend time navigating Israeli checkpoints. However, the delay is perhaps no more a detriment to Palestinian education than regular traffic jams might be in large urban areas elsewhere.

Additionally, though the media regularly suggest that Palestinians deal often - and in burdensome ways - with the Israeli military, this seemed to have little influence on the daily operations of schools in either East Jerusalem or the West Bank. Despite the ongoing presence of Israeli military throughout the region, school leaders did not see the presence of Israeli soldiers as problematic. Rather, only two of the school administrators claimed that the military continued to have a negative influence on Palestinian schools. The majority of school leaders - more than $85 \%$ of those interviewed - made little or no reference to the issue. It seemed clear that most of the school leaders do not see the Israeli military as having a notable influence on Palestinian education today. Although the Israeli military was once very interested in Palestinian education, due to varieties of social and security concerns, they are seen to have distanced themselves from the schools since the end of the first and second intifadas. The activities of most schools continue without any direct and - in many places - even tangential contact with the Israeli military.

Although two school leaders had maintained that Israeli national security creates ongoing challenges for them, the effects are not plainly observable today. At points during the first and second intifadas, the Israeli Defense Force would often enter the schools and deal directly with administrators. Tensions were high between school leaders and the Israeli military, and - since the uprisings were closely linked to Palestinian education - all Palestinian schools were suspect. Today, the Israeli military has withdrawn its presence from most schools; to this end, most school leaders have very few regular dealings with Israelis. For example, when asked whether the Israeli military created ongoing challenges for school leaders, one administrator in East Jerusalem responded, "What can we do? It simply is our reality as Palestinians. It is not easy for anyone, but everyone faces the same problems. We go about our lives, but as a school the IDF doesn't bother us." All school leaders face ongoing obstacles directly related to the Arab-Israeli conflict, yet - aside from two administrators - the 
Israeli Defense Force is not considered one of their ongoing managerial challenges.

When speaking with teachers and other staff members at these two particular schools, it seemed very apparent that the school administrators have each had very negative experiences with the Israeli military in the past. One was arrested and imprisoned for a short period in the 1980 s, while a family member of the other was killed during the second intifada. The personal experiences of these administrators seemed to tangibly influence the ways that the particular schools highlighted a proPalestinian mentality. In the institutions, posters depicting the former PLO leader Yasser Arafat as well as other forms of cultural literature were prominently displayed. In addition, each of the schools each had the Palestinian flag presented in various ways in different parts of the school, such as in drawings on the bulletin boards, on posters, or within classrooms.

Both these schools displayed a very strong Palestinian identity; they presented themselves as deeply proud of their heritage and connected to the struggles facing all Arabs in the region. Those who both worked and attended the school seemed much more aware of themselves as very different from the Israelis. In addition, there was a feel to both the schools that distinguished them from others - they were more expressively Palestinian, quicker to talk about their experiences with the Israelis, and much more vocal about who they perceive themselves to be in the face of Israeli occupation. In these two schools, everyone was very kind and welcoming; when they spoke, they knew the topic very well and had narrated their experiences many times before. Growing up Palestinian is not without its challenges; the issues that teachers, staff members, and students face become part of their educational experience.

One teacher from the West Bank school argued, "For those who live near the school, our lives are almost completely separate from the Jewish [sic] and their soldiers. They mostly do not come into our town since the [Oslo] accords, and our life goes on without them." Most of the issues that could be claimed a result of the military influence seems to relate more with checkpoints and security delays than anything else.

For example, one secretary at an East Jerusalem school confided, "I live in a small room on the school property because I cannot come from my home in Bethlehem to Jerusalem every day. The director allows me to stay for free." Access to the city from the West Bank is difficult for many people; although many make the passage on a daily basis, it is often easier to spend large chunks of time in one region or another. A teacher at the same institution stated,
I am a Jerusalemite who married a man from Beit Jala. He is not allowed to visit Jerusalem because [he has] no permit. I live here [Jerusalem] part of the time because it is difficult to go through checkpoints in the evening and the morning. This means I do not see him for many days at a time.

The checkpoints indeed have a real effect on how quickly and easily both staff and students can get to the schools; this naturally affects their behaviour. One teacher from the West Bank school claimed that he needed to get up daily at 3:30 a.m. in order to ensure that he arrives at his East Jerusalem school by 7:00 a.m. with some time to prepare for the day. Although travel time takes 90 minutes for him, it can sometimes extend to up to three hours. Still, he refuses to allow the situation to hinder his commitment. He explained, "I would much rather be two hours early for the class than a few minutes late." For this particular teacher, there is - for the first time in many years - a routine for him to follow. Despite the tensions that continue to exist between Israel and Palestine, his days reflect an appreciated predictability that was not possible to achieve during the first and second intifadas.

The limited influence that Israeli national security had on the daily routines of most Palestinians was illustrated for me after one Israeli colleague asked me to stand outside the Old City of Jerusalem and watch Israeli soldiers randomly check Palestinian identifications. Following the request, I observed that Israeli soldiers regularly stopped large numbers of Arab men as they made their way into the city. Yet, after observing this on a variety of other occasions, it seemed the checkpoint was an inconvenience but not a major issue with which administrators would need to deal regularly. Of course, the important question is not whether Israel should have checkpoints in East Jerusalem or the West Bank. Rather, it is whether the Israeli military was posing any discernable challenge to Palestinian education as a unified whole. When the administrators were asked for some concrete stories about the ways that Israeli security affects Palestinian education today, there were few specific examples provided.

\section{Conclusion}

Out of fourteen Palestinian school leaders, only two of these - one in East Jerusalem and one in the West Bank - claimed that Israeli national security posed any managerial challenges for their schools. Although their institutions did not reveal any more significant a struggle than others in the region, the administrators each displayed a sense of frustration regarding their own situations. Practically, neither of these two school leaders nor their staff could provide more than a few ambiguous examples. Rather, they spoke vaguely of the checkpoints, violence, and 
oppression. These examples, for better or worse, reflect the challenges facing all Palestinians in the area; they are not necessarily limited to Palestinian schools. Observation of fourteen schools suggests that the trials once faced by school leaders in the region during the two intifadas are essentially no longer present. The Israeli Defence Force no longer closes Palestinian schools arbitrarily, and the Israeli security forces no longer view Palestinian education with great suspicion. With recognition that the various challenges facing Palestinian schools less than a decade ago are now substantially diminished, even in light of the clashes that emerged throughout the region as recently as November 2014, it can be said that these institutions now function with both higher levels of routine and a greater sense of ease than they have since about 2005.

\section{References}

[1] Abu-Saad, I. \& Champagne, D. (2006). Introduction: A historical context of Palestinian Arab education. American Behavioral Scientist, 49, 1035-1051.

[2] al-Haj, M. (1995). Education, empowerment and control: The case of the Arabs in Israel. New York: State University of New York Press.

[3] al-Haq. M. (1990). Punishing a nation: Human rights violations during the Palestinian uprising. Boston: South End Press, p. 12.

[4] Asser, M. (2000, October 13). Lynch mob's brutal attack. BBC News: Middle East, para. 8. Retrieved from http://www.bbc.co.uk

[5] Clinton, B. (2005). My life. New York: Vintage Books, p. 544.

[6] Graff, J. (1991). Palestinian children and Israeli state Violence. Toronto: The Near East Cultural and Educational Foundation of Canada.

[7] Glick, C. (2005). Addressing the root cause of the Arab Israeli conflict. Oxford Journal on Good Governance, 2(2), 31-35, p. 32.

[8] Hussein, Y. (2005). The stone and the pen: Palestinian education during the 1987 intifada. The Radical Teacher, 74, 17-22, p. 17. Retrieved from http://www.jstor.org

[9] Immanuel, J. (1994, August 22). Palestinians to control education by end of month. The Jerusalem Post, p. 02 .

[10] IPCRI. (2003). Peace education school year 20032004. Jerusalem: Israel-Palestine Center for Research and Information. Retrieved from http://www.ipcri.org/files/education.html

[11] JMCC. (2009, May 27). First intifada. Retrieved from http://www.jmcc.org/fastfactspag.aspx
[12] Lockman, Z., \& Benin, J. (1989). Intifada: The Palestinian uprising against Israeli occupation. Boston: South End Press.

[13] Maker, A. (1990). The psychological impact of the intifada on Palestinian children in the occupied West Bank and Gaza: An exploratory study. American Journal of Orthopsychiatry, 60(4) 496-505.

[14] McNally, S. (2002, January 1). Caught in the middle: Letter from Jerusalem. [Letter to the editor]. Columbia Journalism Review. Retrieved from http://www.cjr.org

[15] Miller, T., El-Masri, M., Allodt, F., \& Quota, S. (1999, October). Emotional and behavioral problems and trauma exposure of school-age Palestinian children in Gaza: some preliminary findings. Medicine, Conflict, and Survival, 15(4), 368-378.

[16] Nicolai, S. (2006). Education and chronic crisis in Palestine, p. 1. Retrieved from http://www.fmreview.org/

[17] Palestine Monitor. (2010, March 17). Checkpoints. Retrieved from http://www.palestinemonitor.org/

[18] Ra'ad, B. \& Nafi, J. (2007). The geography of occupation: Palestinian education today. Socialism and Democracy, 21(1). 33-45.

[19] Reuters. (1994, August 24). Palestinians to receive control over education. Toronto Star, p. A15.

[20] Sachs, S. (1995, November 21). Palestinians struggle to build educational system. The Ottawa Citizen, p. D10.

[21] Santisteban, A. V. de (2002). Palestinian education: A national curriculum against all odds. International Journal of Educational Development, 22, 145-154, p. 146.

[22] Sharon, A. \& Chanoff, D. (2001). Warrior. New York: Simon and Schuster, p. 6.

[23] Wallach, J. (2000). The enemy has a face. Washington: United States Institute of Peace Press.

[24] Zureik, E. (2002). Palestinian education in disarray. CAUT - ACCPU Bulletin, 49(5), para 6. Retrieved from http://www.cautbulletin.ca/ 